\title{
10 years after the roadmap: procedural rights in criminal proceedings in the $\mathrm{EU}$ today
}

\author{
Cornelia Riehle $^{1}$ - Allison Clozel ${ }^{2}$
}

Published online: 2 October 2019

(C) Europäische Rechtsakademie (ERA) 2019

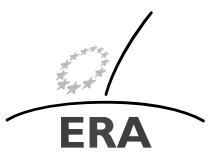

EUROPÄISCHE RECHTSAKADEMIE ACADEMY OF EUROPEAN LAW ACADEMIE DE DROIT EUROPEEN ACCADEMIA DI DIRITTO EUROPEO TRIER - TREVES - TREVIRI

It is the declared aim of the European Union to offer its citizens an area of freedom, security and justice (Art. 3 (2) TEU). However, looking at European criminal justice, for many years the focus lay on security issues with numerous measures taken to enhance police and judicial cooperation in criminal matters in the EU (e.g. the European Arrest Warrant, the setting up of Europol, Eurojust, and the European Public Prosecutor's Office (EPPO)). Furthermore, protection of the rights of accused and suspected persons in criminal proceedings in the EU guaranteed under the European Convention of Human Rights (ECHR) were not sufficient, as the ECHR provides only general rules for a wide variety of 47 contracting states and the ECtHR's interpretation of procedural rights through its case-law is very casuistic since the Court only replies to a particular situation at hand. There is also a lack of an enforcement mechanism for Contracting States to modify their deficient laws.

Realising this imbalance, in the year 2004, the European Commission proposed a Council Framework Decision on certain procedural rights in criminal proceedings throughout the $\mathrm{EU}^{1}$ which, however, could not reach unanimity and hence could not be adopted. Several years later, the work was re-launched in 2009 under the Swedish

\footnotetext{
${ }^{1}$ Proposal for a council framework Decision on certain procedural rights in criminal proceedings throughout the European Union $\{$ SEC(2004) 491\}/* COM/2004/0328 final.
}

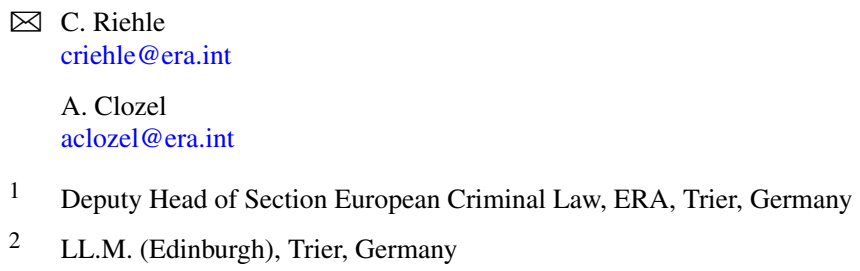


Presidency of the Council of the EU, where agreement was reached on a roadmap for strengthening procedural rights of suspected or accused persons in criminal proceedings. ${ }^{2}$ The roadmap outlined six areas where action should be taken at EU level to strengthen the rights of suspects and accused persons, namely regarding interpretation and translation (1), the information on rights and information about the charges (2), legal advice and legal aid (3), communication with relatives, employers and consular authorities upon arrest (4), special safeguards for vulnerable persons (5), and a green paper on pre-trial detention (6). Following this, the Council endorsed the roadmap, and the European Council made it part of the Stockholm Programme. ${ }^{3}$ Measures to be taken were laid out in the Action Plan Implementing the Stockholm Programme. ${ }^{4}$

In the following years, agreements could be reached on six Directives outlining the rights to interpretation and translation $(2010 / 64 / \mathrm{EU}),{ }^{5}$ to information $(2012 / 13 / \mathrm{EU}),{ }^{6}$ to access to a lawyer $(2013 / 48 / \mathrm{EU}),{ }^{7}$ to legal aid $(2016 / 1919 / \mathrm{EU}),{ }^{8}$ the presumption of innocence $(2016 / 343 / \mathrm{EU}),{ }^{9}$ and procedural safeguards for children suspected or accused in criminal proceedings $(2016 / 800 / \mathrm{EU}) .{ }^{10}$ The Commission has also published a Green Paper on pre-trial detention (COM (2011) 327 final) ${ }^{11}$ and a recommendation on procedural safeguards for vulnerable persons suspected or accused in criminal proceedings. ${ }^{12}$

\footnotetext{
${ }^{2}$ Resolution of the Council of 30 November 2009 on a Roadmap for strengthening procedural rights of suspected or accused persons in criminal proceedings (Text with EEA relevance) (2009/C 295/01).

${ }^{3}$ The Stockholm Programme-An open and secure Europe serving and protecting citizens, OJ C 115; 4.5.2010.

${ }^{4}$ Communication from the Commission to the European Parliament, the Council, the European Economic and Social Committee and the Committee of the Regions-Delivering an area of freedom, security and justice for Europe's citizens-Action Plan Implementing the Stockholm Programme.

${ }^{5}$ Directive 2010/64/EU of the European Parliament and of the Council of 20 October 2010 on the right to interpretation and translation in criminal proceedings, OJEU L 280/1.

${ }^{6}$ Directive 2012/13/EU of the European Parliament and of the Council of 22 May 2012 on the right to information in criminal proceedings, OJEU L 142/1.

${ }^{7}$ Directive 2013/48/EU of the European Parliament and of the Council of 22 October 2013 on the right of access to a lawyer in criminal proceedings and in European arrest warrant proceedings, and on the right to have a third party informed upon deprivation of liberty and to communicate with third persons and with consular authorities while deprived of liberty, OJEU L 294/1.
}

${ }^{8}$ Directive (EU) 2016/1919 of the European Parliament and of the Council of 26 October 2016 on legal aid for suspects and accused persons in criminal proceedings and for requested persons in European arrest warrant proceedings, OJEU L 297/1.

${ }^{9}$ Directive (EU) 2016/343 of the European Parliament and of the Council of 9 March 2016 on the strengthening of certain aspects of the presumption of innocence and of the right to be present at the trial in criminal proceedings, OJEU L 65/1.

${ }^{10}$ Directive (EU) 2016/800 of the European Parliament and of the Council of 11 May 2016 on procedural safeguards for children who are suspects or accused persons in criminal proceedings, L 132/1.

${ }^{11}$ European Commission, REEN PAPER "Strengthening mutual trust in the European judicial area-A Green Paper on the application of EU criminal justice legislation in the field of detention", $\operatorname{COM}(2011)$ 327 final.

${ }^{12}$ Commission Recommendation of 27 November 2013 on procedural safeguards for vulnerable persons suspected or accused in criminal proceedings 2013/C 378/02, OJ C 378/8; See also, recital 27 of Directive 2010/64/EU and recital 26 of Directive 2012/13/EU. 
As to their content, Directive 2010/64/EU covers the rights to interpretation and to translation of "essential documents" in criminal proceedings and proceedings for the execution of an EAW. The deadline for implementation was 27 October 2013.

Directive 2012/13/EU sets out common standards on suspects' and accused persons' rights to information in criminal proceedings and the accusation against them, and the right to information of persons subject to a European Arrest Warrant (EAW). When arrested or subject to European Arrest Warrant proceedings, the suspected or accused person is provided a "letter of rights" and is also entitled to access materials of the case. This Directive was to be implemented by the 2 June 2014.

Directive 2013/48/EU entitles suspected/accused persons or those subject to an EAW to have access to a lawyer in criminal proceedings, to have a third party informed of deprivation of liberty and to communicate with third persons and consular authorities while deprived of liberty. The deadline for implementation was 27 November 2016.

Directive 2016/343/EU covers the presumption of innocence for natural persons only. The main provisions include restrictions on public references to, or indications of, guilt of suspects or accused persons. Natural persons also have the right to remain silent and the privilege against self-incrimination and to be present at trial. This Directive was to be implemented on 1 April 2018.

Directive 2016/800/EU provides for rights to information to children and parties with parental responsibility for them. Children are defined as those under 18. According to these provisions, children and the party with parental responsibility are entitled to be informed of the rights to legal assistance, medical examination, audiovisual recording of questioning, limitations on deprivation of liberty, protection of privacy etc. The party with parental responsibility has the right to accompany. The deadline for implementation was 11 June 2019.

Directive 2016/1919/EU entitles suspects and accused persons in criminal proceedings and those subject to an EAW to legal aid. Member States are required to take into account the specific needs of vulnerable persons when implementing this. In order to grant legal aid, Member States may apply a means and/or merits test in their decisions. The deadline for implementation was 25 May 2019.

Transposition phases for the last of the new Directives expired on 11 June 2019. Hence, since 12 June 2019, legal practitioners in the EU, especially judges, prosecutors and defence lawyers, need to apply the new rights as set out by the Directives in the context of their daily work.

However, as of today, the Directives are still not implemented by all Member States. Taking a look at the status of implementation of the Directives provided by the European Judicial Network (EJN), ${ }^{13}$ it shows that Directive 2010/64/EU is currently in force in 27 Member States; Directive 2012/13/EU still needs to be implemented in Belgium; Directive 2013/48/EU still needs to be implemented in four Member States (Bulgaria, Croatia, Cyprus, Romania). Only three Member States (Czech Republic, Hungary and Portugal) have implemented Directive 2016/343/EU in their domestic legal order. Finally, Directives 2016/800/EU and 2016/1919/EU have so far only been implemented in Poland. ${ }^{14}$

\footnotetext{
${ }^{13}$ https://www.ejn-crimjust.europa.eu/ejn/libcategories/EN/2/-1/0.

${ }^{14}$ Denmark has a general opt-out from the area of freedom, security and justice.
} 
Slowly but constantly, the Court of Justice of the EU (CJEU) strengthens its caselaw by clarifying the scope of these procedural rights. Since 2018, the CJEU has issued 14 judgements shaping the interpretation of procedural rights under the current Directives. At the heart of these judgements, the Court emphasised the primordial importance of mutual recognition and mutual trust among Member States in crossborder criminal proceedings. In particular, the Court interpreted key elements set out in the procedural rights directives such as the notion of "essential documents" 15 that can be translated during criminal proceedings, the length of pre-trial detention ${ }^{16}$ or the independence of the judicial authority ${ }^{17}$ executing the EAW.

Looking at judicial cooperation in criminal matters in the EU, not only procedural safeguards have been developed, but also other instruments of mutual recognition, especially with regard to foreign evidence gathering and the recognition of foreign criminal sentences. The transposition phase of the European Investigation Order ended on 22 May 2017, new proposals for cross-border access to electronic evidence were tabled on 17 April 2018, and mutual recognition measures for pre-trial detention and detention should be available since 2012. Future EPPO proceedings generally require a better, more fairly balanced system of minimum standards after the Regulation 2017/1939 failed to set certain standards for procedural safeguards. Many of these topics are also dealt with in detail in this issue of the ERA Forum. Hence, this issue of the ERA Forum contains articles covering the following topics: common standards for prison and detention conditions in the EU, analysis of current EU counter-terrorism measures, the growing dominance of hacking for evidence, the different forms of online fraud, privacy and security in the digital age, regulation of freezing and confiscations orders, the evolution of the European Arrest Warrant, the ECHR case-law on counter-terrorism, and finally privacy risks with smartphone technology.

Looking at these further developments, 10 years after the roadmap for procedural rights was developed, many legal practitioners feel the need for further action at EU level to strengthen the rights of suspected or accused persons in criminal proceedings. Therefore, the question may be raised if it is time for a second roadmap on procedural rights. In this regard, the ECBA suggested a new roadmap for 2020 aiming at taking further action at EU level to strengthen procedural rights of suspected or accused persons. In this recommendation, the ECBA suggests taking measures regarding pre-trial detention and the EAW, procedural rights in trial, exclusion of evidence, witnesses' rights and confiscatory bans, conflicts of jurisdiction and ne bis in idem, remedies and appeal, and compensation. ${ }^{18}$

An obvious pre-requisite for effective application of the Directives is training among the legal professions mentioned. In response to this, ERA is going to organise a series of seminars, co-financed by the European Commission under its Jus-

${ }^{15}$ C-11 C-216/14 Covaci, Judgment of 15 October 2015 (First Chamber); C-11 Case C-278/16 Frank Sleutjes), Judgment of 12 October 2017 (Fifth Chamber).

${ }^{16}$ Case C-492/18 PPU, Judgment of the Court (First Chamber) 12 February 2019.

${ }^{17}$ C-10 Case C-216/18 PPU, LM, Judgment of 25 July 2018 (Grand Chamber).

${ }^{18}$ ECBA Initiative 2017/2018, "Agenda 2020: A new Roadmap on minimum standards of certain procedural safeguards" available at: http://www.ecba.org/extdocserv/20180424_ECBA_Agenda2020_ NewRoadMap.pdf. 
tice Programme, in the course of 2020 and 2021 looking at the state of play of the six EU Directives on procedural rights and the need for further measures, the case law of the CJEU, procedural rights in the context of the EAW, pre-trial detention and detention, and evidence gathering. Further information on procedural safeguards in the EU can also be found on ERA's website http://www.era-comm.eu/ procedural_safeguards/index.html.

Publisher's Note Springer Nature remains neutral with regard to jurisdictional claims in published maps and institutional affiliations. 